\title{
Molecular Biology of Borrelia burgdorferi
}

\author{
Ali Karami \\ Research Center of Molecular Biology, Baqyiatallah \\ University of Medical Sciences, Tehran
}

Iran

\section{Introduction}

Borrelia may be unique among prokaryote in having a genome that is mainly linear DNA physical and genetic map of linear chromosome of B. burgdurferi has been published, it consist of 946 to $952 \mathrm{~kb}$ Linear DNA (Sherwood et al;1993, Davidson et al;1992, Barbour et al; 1982).

This bacteria also contains several circular and specially linear plasmids from 5 to $55 \mathrm{~kb}$. Recently analysis of entire Agrobacterium tumefaciens C58 genome revealed presence of one 2.1-Mb linear and one 3- Mb circular plasmid (Servent et al; 1993) and it has been shown that rhodococcus fascians contains $4 \mathrm{Mb}$ linear chromosome (Crespi et al; 1992). Presence of several linear plasmids seems the segmentation of Borrelias DNA to several linear pieces has led to the suggestion that the relatively small linear chromosome and the linear plasmids actually are minichromosoms. In $B$. hermsii it has been shown that total cellular DNA organized into several complete gnomes (Kitten et al; 1992) and it suggests that linear plasmids are like small chromosomes (Ferdows et al; 1989). Plasmid profile of B. burgdorferi from different geographical area has been revealed significant heterogeneity a feature that can be used for classification of bacteria within given species (Barbour et al; 1987, 1989). Another related spirochete $B$. hermsii like $B$. burgdorferi has several linear and circular plasmids and the genes responsible for antigenic variation are located in linear plasmids. In B. burgdorferi a $49 \mathrm{~kb}$ linear plasmid carries the genes for Outer Surface Protein A and B (OspA and OspB) (Barbour et al; 1987, Baril et al; 1989). It has been shown that passage of B. burgdorferi in BSK medium changes the plasmid profile and loss of plasmids may change the infectivity of organism (Schwan et al; 1988, Simpson, et al; 1990). Structure of Linear plasmids of $B$. burgdorferi shows similarity to eukaryotic virus such as vaccinia and African swine fever virus in having covalently closed ends like hairpin loops (Hinnebusch et al; 1991).

\subsection{Taxonomy and classification}

Borrelia burgdorferi belongs to the phylum Spirochaetes. The members of this phylum are long, thin, helically coiled bacteria that have flagella (axial filaments) running lengthwise between the peptidoglycan layer and the outer membrane. Movement of the flagellum produces a screw-like motion that propels the organism.

The phylum Spirochates contains a single class (Spirochaetes), a single order (Spirochaetales), and three families: Brachyspiraceae, Leptospiraceae, and Spirochaetaceae. 


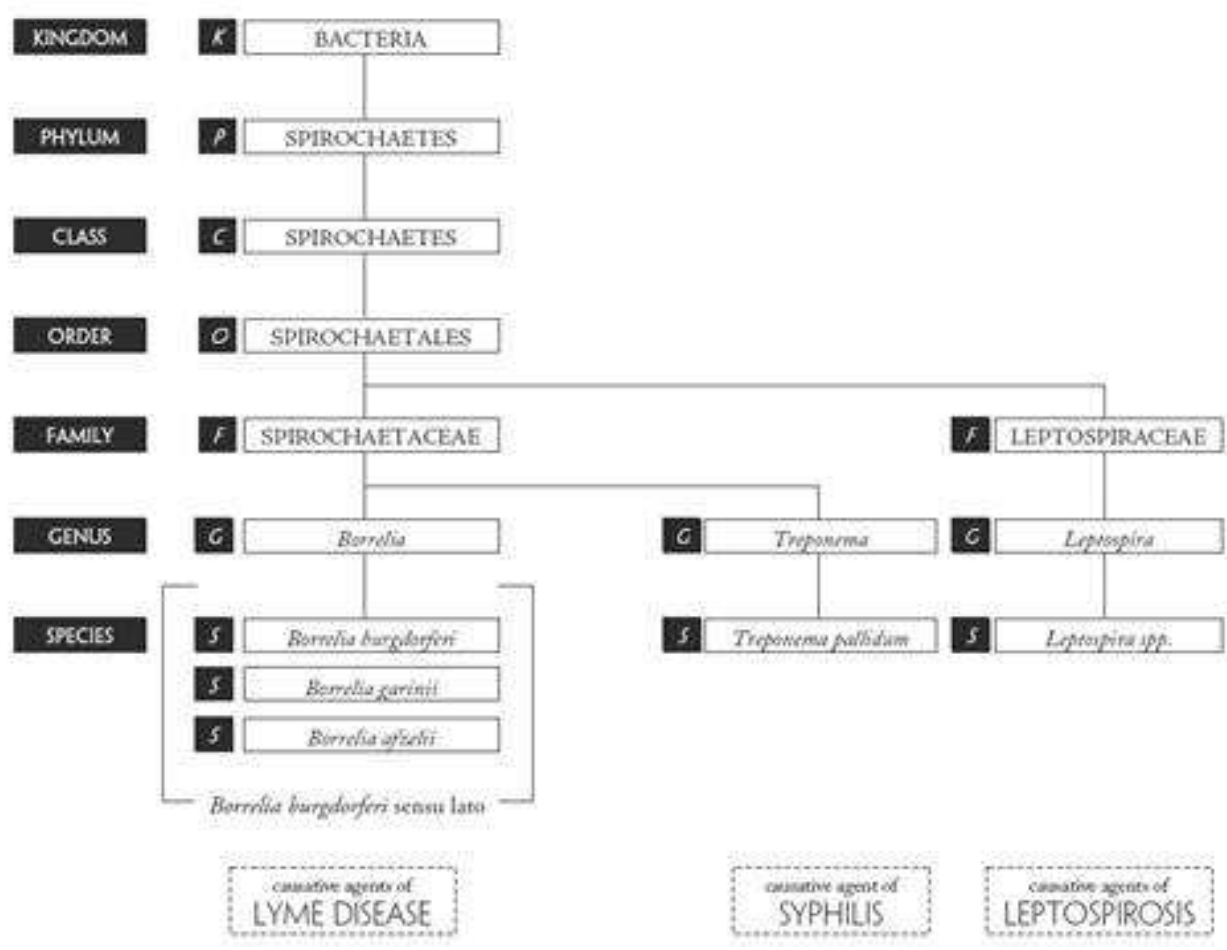

Fig. 1. Spirochaetaceae

The Spirochaetaceae family includes the genus Treponema and the genus Borrelia . Treponema pallidum is the causative agent of the sexually-transmitted disease syphilis.

The three members of the Borrelia genus Borrelia burgdorferi sensu stricto, Borrelia garinii, and Borrelia afzelii are collectively known as Borrelia burgdorferi sensu lato, and are the causative agents of Lyme disease.

\subsection{Structure and morphology}

Borrelia cells average 0.2 to $0.5 \mu \mathrm{m}$ by 4 to $18 \mu \mathrm{m}$, and have fewer coils than Leptospira. The periplasmic flagella originate from either end of the spirochete (where they are anchored to the cytoplasmic membrane) and wind around the protoplasmic cylinder, imparting both motility and shape to the organism-in contrast to other bacteria, in which the peptidoglycan layer determines the shape.

The role of flagella in imparting Borrelia 's helical shape was established by inactivation of the $f l a B$ gene, which encodes the major flagellar filament protein, FlaB. This produced bacteria that lacked periplasmic flagella, were non-motile and rod-shaped.

Whereas the motility of externally-flagellated bacteria is hindered in viscous substances, that of spirochetes is enhanced, and about $6 \%$ of the chromosomal genome encodes proteins involved in motility and chemotaxis. 


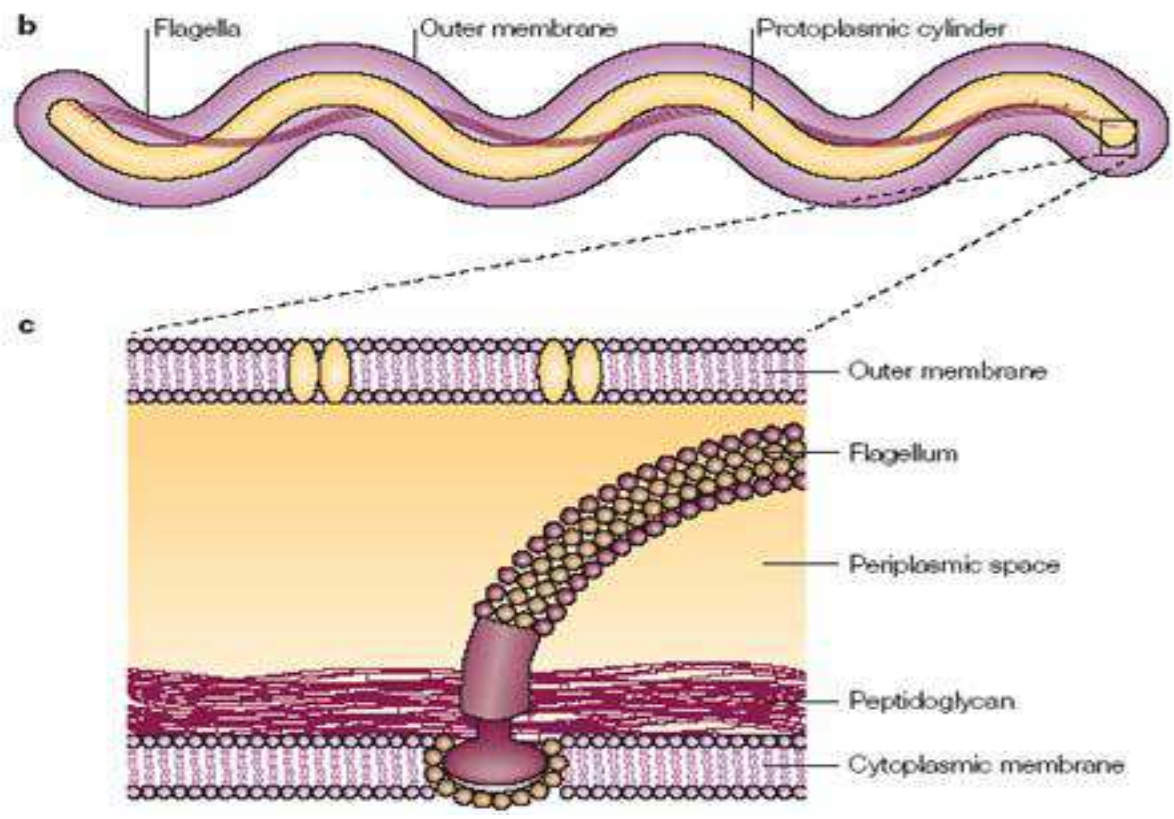

Fig. 2.

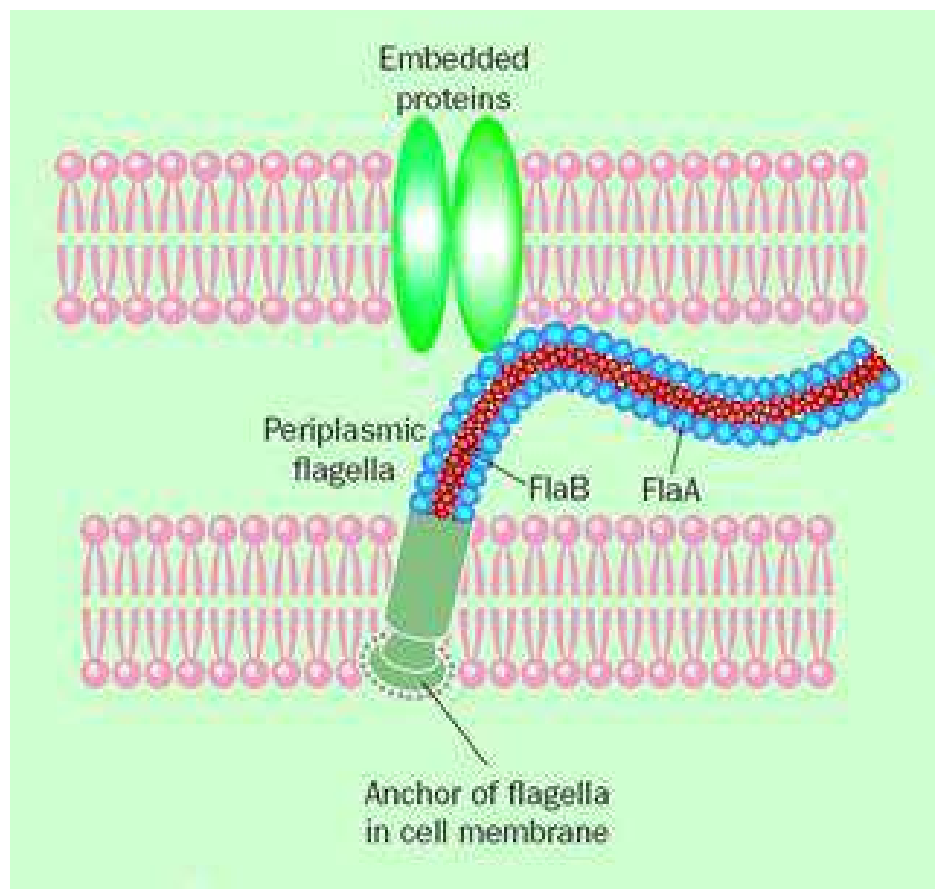

Fig. 3. 


\subsection{Genome organization of Borrelia burgdorferi}

All members of the Borrelia genus that have been examined harbor a linear chromosome that is about $900 \mathrm{kbp}$ in length as well as a plethora of both linear and circular plasmids in the 5$220 \mathrm{kbp}$ size range. Genome sequences have been determined for B. burgdorferi, B. garinii, B. afzelii, $B$. duttonii and $B$. recurrentis. The chromosomes, which carry the vast majority of the housekeeping genes, appear to be very constant in gene content and organization across the genus. The content of the plasmids, which carry most of the genes that encode the differentially-expressed surface proteins that interact with Borrelia's arthropod and vertebrate hosts, are much more variable. B. burgdorferi strain B31, the B. burgdorferi type strain, has been studied in the most detail and harbors twelve linear and nine circular plasmids that comprise about $612 \mathrm{kbp}$. The plasmids are unusual, as compared to most bacterial plasmids, in that they contain many paralogous sequences, a large number of pseudogenes and, in some cases, essential genes. In addition, a number of the plasmids have features suggesting that they are prophages. Some correlations between genome content and pathogenicity have been deduced and comparative whole genome analyses promise future progress in this arena.

The highly unusual segmented genomes of Borrelia species can contain over 20 utonomously replicating DNA molecules. Many of the molecules, including the chromosome, are linear with covalently closed hairpin ends.

\section{Molecular biology}

\subsection{The Borrelia burgdorferi genome}

The genome of Borrelia burgdorferi consists of a single linear chromosome and several plasmids, both linear and circular. To date-as of January 2005-only the genome of Borrelia burgdorferi sensu stricto B31 strain has been fully sequenced.

\begin{tabular}{|c|c|c|}
\hline Distribution of cellular functions & $l i$ and $B$. burgdorferi genes & [1] \\
\hline Category & B. burgdorferi genes (\%) & \\
\hline Intermediary metabolism & $4.9 \%$ & \\
\hline Biosynthesis of small molecules & $3.1 \%$ & \\
\hline Macromolecule metabolism & $22.2 \%$ & \\
\hline Cell Structure & $37.0 \%$ & \\
\hline Cellular processes & $7.4 \%$ & \\
\hline Other functions & $5.6 \%$ & \\
\hline Unknown functions & $19.8 \%$ & \\
\hline
\end{tabular}

Table 1. 


\subsection{Chromosomal genome}

B. burgdorferi contains a single linear chromosome of approximately $900 \mathrm{~kb}$, and about $90 \%$ of it is comprised of coding sequences. Most of the genes encoded by the chromosomal genome are homologous to genes of known function.

\subsection{Extra-chromosomal genome}

The extra-chromosomal genome of B. burgdorferi B31 consists of 12 linear plasmids and nine circular plasmids that total $610 \mathrm{~kb}$ in size.

\subsubsection{Linear plasmids}

There are two linear plasmids in B. burgdorferi that are absolutely necessary for persistent infection of a mammalian host. These plasmids, known as 1 p25 and 1p28-1, are relatively unstable in culture, and are commonly lost after a few generations of in vitro growth. Bacteria that have lost either of these two plasmids remain capable of in vitro growth, but lose their ability to cause persistent infection even in immunocompromised mice. The lp25 plasmid contains a gene, $p n c A$, which encodes a nicotinamidase whose function is most likely the biosynthesis of NAD; by all appearances its activity is dispensable growth in vitro, but crucial for growth within a host. Transforming the lp25- spirochetes with pncA on a shuttle vector replaces the requirement of 1 p25 in vivo. Likewise, reintroduction of the entire 1p25 plasmid (by transformation) into 1 p25- spirochetes successfully rescues infectivity. [2]

\subsubsection{Circular plasmids}

An unusual feature of B. burgdorferi is a series of related 32-kb circular plasmids, termed cp32s. These have been found to be prophage genomes, and it is believed that they play a role in the horizontal transfer of DNA among spirochetes that share a common geographical and ecological niche. $[3,4]$

\subsubsection{OuterSurface Proteins (Osps)}

The Outer Surface Proteins (Osps) of B. burgdorferi are lipoproteins that play an important role in interacting with interstitial and cellular components of insect and mammalian hosts. OspA, the most studied of the Osps, is expressed on spirochetes in unfed nymphs and adult ticks, as well as in culture. OspA mediates adherence to the cells of the tick midgut, which presumably allows spirochetes to avoid endocytosis by tick gut cells during digestion of the blood meal. The ability of Borrelia to regulate expression of OspA indicates that it also plays a role in detachment from the midgut, which allows the bacteria to enter the mammalian host when the tick takes a second bloodmeal.

During tick feeding, Borrelia in the midgut upregulate expression of another outer surface protein, OspC, and begin to move toward the salivary glands. This evident correlation suggests that OspC might play a role in transmission. Once it has entered the mammalian host, Borrelia downregulates OspA and exhibits variable OspC upregulation patterns. Although B. burgdorferi possesses only one copy of the ospC gene, sequences vary significantly from one strain to the next, which accounts for the observed antigenic variation 
between OspC proteins. The host immune system plays an important role in selecting for certain strains by eliminating the immunodominant ones.

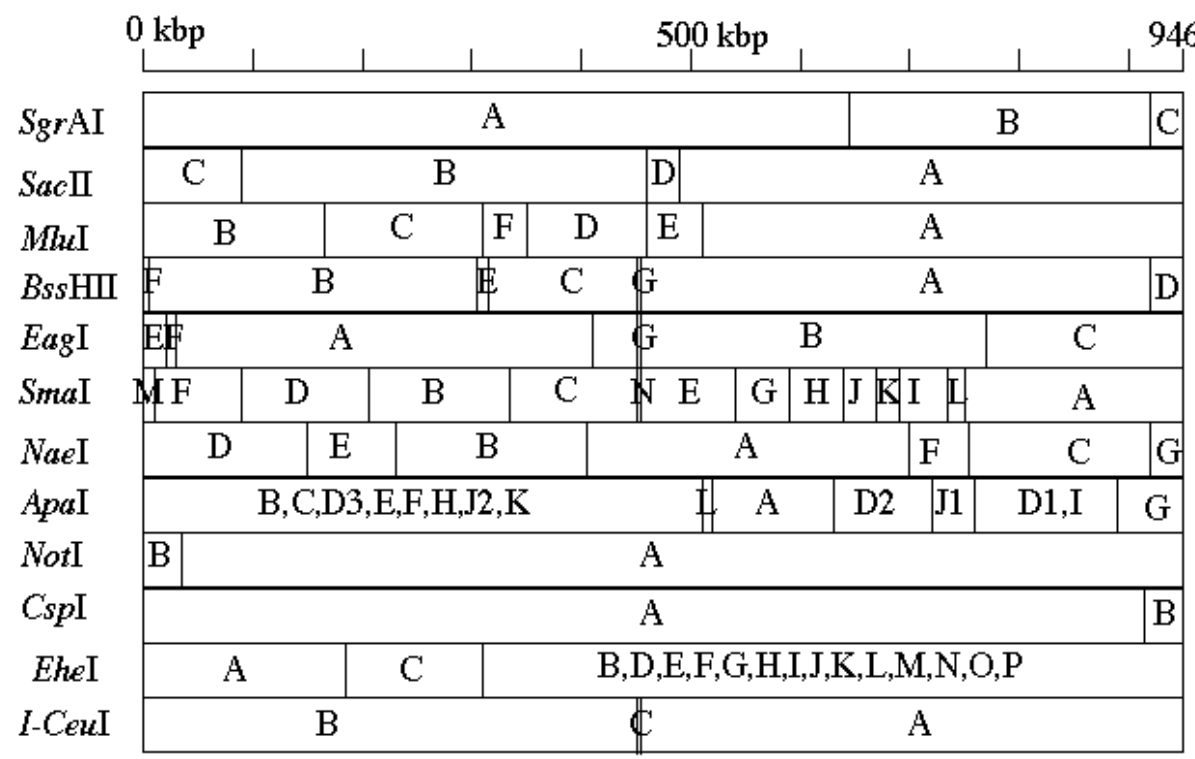

Physical map of the linear chromosome of Borrelia burgdorferi 212

Fig. 4.

\section{Genome features in Borrelia burgdorferi}

Chromosome 910,725 bp (28.6\% G+C)

Coding sequences $(93 \%)$

RNAs $(0.7 \%)$

Intergenic sequence $(6.3 \%)$

853 coding sequences

$500(59 \%)$ with identified database match

$104(12 \%)$ match hypothetical proteins

249 (29\%) with no database match

\section{Plasmids}

cp9 9,386 bp (23.6\% GC)

cp26 26,497 bp (26.3\% GC) 
lp17 16,828 bp (23.1\% GC)

lp25 24,182 bp (23.3\% GC)

lp28-1 26,926 bp (32.3\% GC)

lp28-2 29,771 bp (31.5\% GC)

lp28-3 28,605 bp (25.1\% GC)

lp28-4 27,329 bp (24.4\% GC)

lp36 36,834 bp (26.8\% GC)

lp38 38,853 bp (26.1\% GC)

lp54 53,590 bp (28.1\% GC)

Coding sequences (71\%)

Intergenic sequence (29\%)

430 coding sequences

$70(16 \%)$ with identified database match

$110(26 \%)$ match hypothetical proteins

$250(58 \%)$ with no database match

\section{Ribosomal RNA Chromosome coordinates}

16S 444581-446118

23S 438590-441508

5S 438446-438557

23S 435334-438267

5S 435201-435312

\section{Stable RNA}

tmRNA 46973-47335

mpB 750816-751175

\section{Transfer RNA}

34 species ( 8 clusters, 14 single genes)

*The telomeric sequences of the nine linear plasmids assembled as part of this study were not determined; estimation of the number of missing terminal nucleotides by restriction analysis suggests that less than 1,200 bp is missing in all cases. Comparisons with previously determined sequences of $1 \mathrm{p} 16.9$ and one terminus of $1 \mathrm{p} 28-1$ indicate that 25, 60 and 1,200 bp are missing, respectively.

\section{Chromosomally-encoded genes}

- $\quad$ rRNA sequences

- fla sequences

- $\quad$ hbb sequences

- $\quad$ fesmid sequences 


\subsection{Borrelia burgdorferi rRNA sequences}

\begin{tabular}{|c|c|c|c|c|c|}
\hline Genbank mnemomic & $\begin{array}{l}\text { Accession } \\
\text { number }\end{array}$ & Description & Strain & $\begin{array}{l}\text { Date of } \\
\text { entry }\end{array}$ & Size \\
\hline Gb_ba:Bbrnaopr & U03396 & $\begin{array}{l}\text { alaT (Ala-tRNA ), ileT } \\
\text { (Ile-tRNA), rrs (16S } \\
\text { rRNA), rrlA \& rrlB } \\
\text { (23S rRNA) rrfA \& rrfB } \\
\text { (5S rRNA) }\end{array}$ & B31 & $10 / 93$ & 11955bp \\
\hline Gb_ba:Bbu44938 & U44938 & rrs (16S rRNA) & $5 \mathrm{MT}$ & $5 / 96$ & $1,533 \mathrm{bp}$ \\
\hline Gb_ba:Bor16rg & L39080 & rrs (16S rRNA) & 9MT & $3 / 95$ & $1,533 b p$ \\
\hline Gb_ba:Bbu44939 & U44939 & rrs (16S rRNA) & $917 Y$ & $5 / 96$ & $1,533 b p$ \\
\hline Gb_ba:Bb16s297 & X85204 & rrs (16S rRNA) & 297 & $5 / 95$ & $1,488 \mathrm{bp}$ \\
\hline Gb_ba:Borrrd & L36160 & rrs (16S rRNA) & $934 \mathrm{U}$ & $9 / 94$ & $1,536 \mathrm{bp}$ \\
\hline Gb_ba:Bor16rga & L39081 & rrs (16S rRNA) & $935 \mathrm{~T}$ & $3 / 95$ & $1,542 b p$ \\
\hline Gb_ba:Borrrdq & M64309 & rrs (16S rRNA) & 1352 & $4 / 92$ & $1,481 \mathrm{bp}$ \\
\hline Gb_ba:Borrrd & M64310 & rrs (16S rRNA) & 20004 & $4 / 92$ & $1,480 \mathrm{bp}$ \\
\hline Gb_ba:Bb16srrna & X57404 & rrs (16S rRNA) & B31 & $3 / 92$ & $1,465 b p$ \\
\hline Gb_ba:Borssrna & M59293 & rrs (16S rRNA) & B31 & $4 / 92$ & $1,480 \mathrm{bp}$ \\
\hline Gb_ba:Borrnaca & M89935 & rrs (16S rRNA) & CA2-87 & $1 / 93$ & 1,291bp \\
\hline Gb_ba:Bb16sdk7 & X85195 & rrs (16S rRNA) & DK7 & $5 / 95$ & $1,488 \mathrm{bp}$ \\
\hline Gb_ba:Bb16sdk29 & X85202 & rrs (16S rRNA) & DK29 & $5 / 95$ & $1,488 \mathrm{bp}$ \\
\hline Gb_ba:Bb16sdunk & X85201 & rrs (16S rRNA) & DUNKIRK & $5 / 95$ & $1,488 \mathrm{bp}$ \\
\hline Gb_ba:Bbu28501 & U28501 & rrs (16S rRNA) & ESP-1 & $7 / 95$ & $1,488 \mathrm{bp}$ \\
\hline Gb_ba:Borrr16sa & M60967 & $r r s$ (16S rRNA) & G2 & $4 / 92$ & $1,483 \mathrm{bp}$ \\
\hline Gb_ba:Borrnail & M89936 & rrs (16S rRNA) & Illinois 1 & $1 / 93$ & 1,291bp \\
\hline Gb_ba:Bb16skipp & X85196 & $r r s$ (16S rRNA) & KIPP & $5 / 95$ & $1,488 \mathrm{bp}$ \\
\hline Gb_ba:Bb16slipz & X85203 & $r r s$ (16S rRNA) & LIPITZ & $5 / 95$ & $1,488 \mathrm{bp}$ \\
\hline Gb_ba:Borrr16sc & M60969 & rrs (16S rRNA) & Sh-2-82 & $4 / 92$ & $1,476 \mathrm{bp}$ \\
\hline Gb_ba:Borrnavs & M89938 & $r r s$ (16S rRNA) & VS219 & $1 / 93$ & $1,350 \mathrm{bp}$ \\
\hline Gb_ba:Borrgda & L40596 & $r r s$ (16S rRNA) & & $3 / 95$ & $1,492 b p$ \\
\hline
\end{tabular}




\begin{tabular}{|l|l|l|l|l|l|}
\hline Genbank mnemomic & $\begin{array}{l}\text { Accession } \\
\text { number }\end{array}$ & Description & Strain & $\begin{array}{l}\text { Date of } \\
\text { entry }\end{array}$ & Size \\
\hline Gb_ba:Borrg16s & M88329 & rrs (16S rRNA) & & $11 / 93$ & $1,537 \mathrm{bp}$ \\
\hline Gb_ba:Bor23srrna & M93664 & rr1 (23S rRNA) & 212 & $6 / 92$ & $398 \mathrm{bp}$ \\
\hline Gb_ba:Bb23s5s & X85745 & rrl rrs (23S \& 5S rRNA) & B31 & $7 / 95$ & $2,093 \mathrm{bp}$ \\
\hline Gb_ba:Borrg23s & M88330 & rr1 (23S rRNA) & & $1 / 93$ & $2,926 \mathrm{bp}$ \\
\hline Gb_ba:Bb523srr & X57791 & $\begin{array}{l}\text { rrf (5S) and } r r l(23 S \\
\text { rRNA genes). }\end{array}$ & $6 / 93$ & $616 \mathrm{bp}$ \\
\hline Gb_ba:Borburssp & L30121 & $\begin{array}{l}\text { internal transcribed } \\
\text { spacer }\end{array}$ & 212 & $7 / 94$ & $253 \mathrm{bp}$ \\
\hline Gb_ba:Borburs2sp & L30127 & $\begin{array}{l}\text { internal transcribed } \\
\text { spacer }\end{array}$ & B31 & $7 / 94$ & $254 \mathrm{bp}$ \\
\hline Gb_ba:Borburg7sp & L30123 & $\begin{array}{l}\text { internal transcribed } \\
\text { spacer }\end{array}$ & CA2 & $7 / 94$ & $255 \mathrm{bp}$ \\
\hline
\end{tabular}

Table 2.

3.2 Borrelia burgdorferi fla sequences

\begin{tabular}{|l|l|l|l|l|l|}
\hline $\begin{array}{l}\text { Genbank } \\
\text { mnemomic }\end{array}$ & $\begin{array}{l}\text { Accession } \\
\text { number }\end{array}$ & Description & Strain & $\begin{array}{l}\text { Date of } \\
\text { entry }\end{array}$ & Size \\
\hline Gb_ba:Borflass & L29234 & fla (flagellin) & 212 & $7 / 94$ & $193 \mathrm{bp}$ \\
\hline Gb_ba:Bbfaa & X16833 & $\begin{array}{l}\text { fla flagellum- } \\
\text { associated 41kD } \\
\text { antigen (flagellin) }\end{array}$ & B31 & 9/93 & $1,435 \mathrm{bp}$ \\
\hline Gb_ba:Bbfla2 & X15661 & fla (flagellin) & B31 & $2 / 94$ & $1,011 \mathrm{bp}$ \\
\hline Gb_ba:Borflab31a & L29200 & fla (flagellin) & B31 & $7 / 94$ & $193 \mathrm{bp}$ \\
\hline Gb_ba:Borflag & M34710 & fla (flagellin) & B31 & $5 / 95$ & $684 \mathrm{bp}$ \\
\hline Gb_ba:Bbbop41 & X69607 & $\begin{array}{l}\text { fla flagellum- } \\
\text { associated 41kD } \\
\text { antigen (flagellin) }\end{array}$ & BO & $5 / 94$ & $1,008 \mathrm{bp}$ \\
\hline Gb_ba:Bbgehofla & X56334 & fla (flagellin) & GeHo & $4 / 93$ & $1,426 \mathrm{bp}$ \\
\hline Gb_ba:Bbfla & X15660 & fla (flagellin) & GeHo & $2 / 94$ & $1,011 \mathrm{bp}$ \\
\hline
\end{tabular}




\begin{tabular}{|c|c|c|c|c|c|}
\hline $\begin{array}{l}\text { Genbank } \\
\text { mnemomic }\end{array}$ & $\begin{array}{l}\text { Accession } \\
\text { number }\end{array}$ & Description & Strain & $\begin{array}{l}\text { Date of } \\
\text { entry }\end{array}$ & Size \\
\hline Gb_ba:Bbflagen & X75200 & fla (flagellin) & HB19 & $8 / 95$ & $1,117 \mathrm{bp}$ \\
\hline Gb_ba:Bbflagen & X75200 & fla (flagellin) & HB19 & $12 / 93$ & $1,117 \mathrm{bp}$ \\
\hline Gb_ba:Bbhep41 & X69609 & $\begin{array}{l}\text { fla flagellum- } \\
\text { associated } 41 \mathrm{kD} \\
\text { antigen (flagellin) }\end{array}$ & $\mathrm{HE}$ & $5 / 94$ & $1,011 b p$ \\
\hline Gb_ba:Bbkap41 & X69611 & $\begin{array}{l}\text { fla flagellum- } \\
\text { associated } 41 \mathrm{kD} \\
\text { antigen (flagellin) }\end{array}$ & KA & $5 / 94$ & $1,008 \mathrm{bp}$ \\
\hline Gb_ba:Bor2fla & L42881 & fla (flagellin) & KL10 & $6 / 95$ & $1,011 b p$ \\
\hline Gb_ba:Bor1fla & L42876 & fla (flagellin) & NBS1ab & $6 / 95$ & $1,011 b p$ \\
\hline Gb_ba:Borflac & M67458 & fla (flagellin) & PSto & $5 / 92$ & $226 b p$ \\
\hline Gb_ba:Bbtrop41 & X69614 & $\begin{array}{l}\text { fla flagellum- } \\
\text { associated } 41 \mathrm{kD} \\
\text { antigen (flagellin) }\end{array}$ & $\mathrm{TRO}$ & $5 / 94$ & $1,011 b p$ \\
\hline
\end{tabular}

Table 3.

\subsection{Borrelia burgdorferi hbb sequences}

\begin{tabular}{|l|l|l|l|l|l|}
\hline $\begin{array}{l}\text { Genbank } \\
\text { mnemomic }\end{array}$ & $\begin{array}{l}\text { Accession } \\
\text { number }\end{array}$ & Description & Strain & $\begin{array}{c}\text { Date of } \\
\text { entry }\end{array}$ & Size \\
\hline Gb_ba:Bbu48650 & $\mathrm{U} 48650$ & $h b b$ (Histone like protein HBbu) & A44S & $4 / 96$ & $327 \mathrm{bp}$ \\
\hline Gb_ba:Bbu48648 & $\mathrm{U} 48648$ & $h b b$ (Histone like protein HBbu) & B31 & $4 / 96$ & $327 \mathrm{bp}$ \\
\hline Gb_ba:Bbu48652 & $\mathrm{U} 48652$ & $h b b$ (Histone like protein HBbu) & IP1 & $4 / 96$ & $327 \mathrm{bp}$ \\
\hline Gb_ba:Bbu48653 & $\mathrm{U} 48653$ & $h b b$ (Histone like protein HBbu) & IP2 & $4 / 96$ & $327 \mathrm{bp}$ \\
\hline Gb_ba:Bbu48648 & $\mathrm{U} 48648$ & $h b b$ (Histone like protein HBbu) & B31 & $4 / 96$ & $327 \mathrm{bp}$ \\
\hline Gb_ba:Bbu48649 & $\mathrm{U} 48649$ & $h b b$ (Histone like protein HBbu) & $\begin{array}{l}\text { NY13- } \\
87\end{array}$ & $4 / 96$ & $327 \mathrm{bp}$ \\
\hline Gb_ba:Bbu48654 & $\mathrm{U} 48654$ & $h b b$ (Histone like protein HBbu) & IP3 & $4 / 96$ & $327 \mathrm{bp}$ \\
\hline Gb_ba:Bbu35673 & $\mathrm{U} 35673$ & $h b b$ (Histone like protein HBbu) & Sh-2-82 & $10 / 95$ & $3,399 \mathrm{bp}$ \\
\hline
\end{tabular}

Table 4. 
3.4 Borrelia burgdorferi fesmid sequences

\begin{tabular}{|l|l|l|l|l|l|}
\hline $\begin{array}{l}\text { Genbank } \\
\text { mnemomic }\end{array}$ & $\begin{array}{l}\text { Accession } \\
\text { number }\end{array}$ & Description & Strain & $\begin{array}{l}\text { Date of } \\
\text { entry }\end{array}$ & Size \\
\hline Gb_ba:Bbu43739 & U43739 & Genes noted below & B31 & $1 / 96$ & $34,817 \mathrm{bp}$ \\
\hline
\end{tabular}

Table 5.

orf38 (open reading frame);

orf37 (open reading frame);

orf36 (open reading frame);

ylxH (putative ATP-binding protein);

flhF (flagella asociated putative GTP-binding protein protein);

flhA (flagellar protein required for flagellar formation);

flhB (flagellar protein required for flagellar formation);

$f l i R$ (flagellar protein required for flagellar formation);

$f l i Q$ (flagellar protein required for flagellar formation);

$f l i P$ (flagellar protein required for flagellar formation);

fliZ (flagellar protein required for flagellar formation);

fliN (flagellar switch protein);

fliM (flagellar switch protein);

orf25 (open reading frame);

motB (flagellar motor rotation protein B);

motA (flagellar motor rotation protein $\mathrm{A}$ );

$f l g E$ (flagellar hook protein);

ylxG (flagellar synthesis);

orf20 (open reading frame);

orf19 (open reading frame);

orf18 (open reading frame);

fliI (flagellar synthesis);

fliH (flagellar synthesis);

fliG (flagellar switch protein);

fliF (flagella basal-body M ring protein);

fliE (flagella basal-body protein);

$f l g C$ (flagella associated rod protein);

$f l g B$ (flagella associated rod protein);

hsll heat shock protein);

$h s l V$ (heat shock protein);

smg (?);

orf7 (open reading frame);

ftsZ (cell division protein);

ftsA (cell division protein);

divIB (cell division protein);

ftsW (cell division protein);

mraY (phosphotransferase);

murF (pentapeptide presynthetase) 
3.5 Borrelia burgdorferi chromosomal sequences (Except rrn \& fla genes)

\begin{tabular}{|c|c|c|c|c|c|}
\hline $\begin{array}{l}\text { Genbank } \\
\text { mnemomic }\end{array}$ & $\begin{array}{l}\text { Accession } \\
\text { number }\end{array}$ & Description & Strain & $\begin{array}{l}\text { Date of } \\
\text { entry }\end{array}$ & Size \\
\hline Gb_ba:Borp39ant & L24194 & $\begin{array}{l}b m p A \text { bmpB (immunodo-minant } \\
\text { antigen P39 gene) }\end{array}$ & Sh-2-82 & $7 / 94$ & $2,304 b p$ \\
\hline Gb_ba:Borbmpa & L35050 & $\begin{array}{l}b m p A \text { bmpB (membrane } \\
\text { lipoproteins A \& B }\end{array}$ & 212 & $12 / 94$ & $904 b p$ \\
\hline Gb_ba:Borbmpc & L34547 & $b m p C$ (membrane lipoprotein C) & 297 & $11 / 94$ & $1,293 \mathrm{bp}$ \\
\hline Gb_ba:Bbu35450 & L34547 & $b m p D$ (membrane lipoprotein D) & 297 & $4 / 96$ & $1,525 \mathrm{bp}$ \\
\hline Gb_ba:Bbcheagen & X91907 & cheA1 (histidine kinase) & 212 & $9 / 95$ & $332 \mathrm{bp}$ \\
\hline Gb_ba:Bbu28962 & $\mathrm{U} 28962$ & cheA1 (histidine kinase) & CT-1 & $6 / 95$ & $2,491 b p$ \\
\hline Gb_ba:Borchea & L39965 & cheA2 (histidine kinase) & B31 & $8 / 95$ & $2,410 \mathrm{bp}$ \\
\hline Gb_ba: Bbu34384 & U34384 & $\begin{array}{l}\text { cheW (Positive regulator of CheA } \\
\text { activity) }\end{array}$ & CT-1 & $9 / 95$ & $660 \mathrm{bp}$ \\
\hline Gb_ba:Bbu04527 & U04527 & $\begin{array}{l}\text { dnaA (DNA replication } \\
\text { initiatior), dnaN (DNA } \\
\text { polymerase III beta subunit), gyrB } \\
\text { (DNA gyrase B subunit), rpmH } \\
\text { (ribosomal pro-tein L34) and } \\
\text { rnpA (ribonuclease P protein } \\
\text { component) }\end{array}$ & 212 & $2 / 94$ & $4943 b p$ \\
\hline Gb_ba:Borgrpepls & M96847 & $\begin{array}{l}\text { dnaJ dnaKand grpE (heat shock } \\
\text { proteins) }\end{array}$ & & $2 / 93$ & $3913 b p$ \\
\hline Gb_ba:Bordnaj & M97914 & dnaJ(heat-shock protein) & CA12 & $12 / 92$ & $1,094 \mathrm{bp}$ \\
\hline Gb_ba:Borhsp70a & M97912 & dnaK (70 kDa heat shock protein) & CA12 & $10 / 92$ & $1,928 \mathrm{bp}$ \\
\hline Gb_ba:S42385 & S42385 & dnaK (70 kDa heat shock protein) & CA12 & $10 / 92$ & $1,911 \mathrm{bp}$ \\
\hline Gb_ba:Bbhspro & X67646 & dnaK (70 kDa heat-shock protein) & ZS7 & $8 / 92$ & $2,116 \mathrm{bp}$ \\
\hline Gb_ba:Bbu12870 & U12870 & flgE (flagellar hook polypeptide) & N40 & $4 / 95$ & $1,552 \mathrm{bp}$ \\
\hline Gb_ba:Bbu19712 & U19712 & flgE (flagellar hook polypeptide) & B31 & $1 / 95$ & $571 \mathrm{bp}$ \\
\hline Gb_ba:Borflge & L43849 & flgE (flagellar hook polypeptide) & HB19 & $8 / 95$ & 1499bp \\
\hline Gb_ba:Borflif & L40501 & fliF (Flagellar MS-ring protein) & 212 & $2 / 96$ & $1717 \mathrm{bp}$ \\
\hline Gb_ba:BBU09711 & U09711 & fliG (Flagellar switch protein) & 212 & $7 / 95$ & $1035 \mathrm{bp}$ \\
\hline Gb_ba:Borflih & L40502 & $f l i H$ (export of flagellar proteins?) & 212 & $1 / 96$ & $921 \mathrm{bp}$ \\
\hline Gb_ba:Borflii & L43325 & fliI (export of flagellar proteins?) & 212 & $1 / 96$ & $1311 \mathrm{bp}$ \\
\hline
\end{tabular}




\begin{tabular}{|c|c|c|c|c|c|}
\hline $\begin{array}{l}\text { Genbank } \\
\text { mnemomic }\end{array}$ & $\begin{array}{l}\text { Accession } \\
\text { number }\end{array}$ & Description & Strain & $\begin{array}{l}\text { Date of } \\
\text { entry }\end{array}$ & Size \\
\hline Gb_ba:Bbftszg & Z12164 & ftsZ (cell division protein) & 212 & $5 / 94$ & $261 b p$ \\
\hline Gb_ba:Bbu28760 & U28760 & $\begin{array}{l}\text { gapDH (glyceraldehyde-3- } \\
\text { phosphate dehydro-genase); pgk } \\
\text { phosphogly-cerate kinase; tpi } \\
\text { triose-phosphate isomerase }\end{array}$ & B31 & $6 / 95$ & $798 b p$ \\
\hline Gb_ba:Bbgidag & Z12160 & $\begin{array}{l}\text { gidA (glucose inhibited division } \\
\text { protein) }\end{array}$ & 212 & $5 / 94$ & 196bp \\
\hline Gb_ba:Bbhsp60 & X65139 & groEL(common antigen) & ZS7 & $5 / 92$ & $1,931 b p$ \\
\hline Gb_ba:Bbgyrag & Z12165 & gyrA (DNA gyrase subunit A) & 212 & $5 / 94$ & $289 \mathrm{bp}$ \\
\hline Gb_ba:Bbgyrbg & Z12166 & gyrB(DNA gyrase subunit B) & 212 & $5 / 94$ & $253 b p$ \\
\hline Gb_ba:Borhtpg & L32145 & htpG (C62.5 heat shock protein) & 212 & $12 / 94$ & 236bp \\
\hline Gb_ba:Borlonaa & L77216 & lon ATP-dependent protease & B31 & $4 / 96$ & 2,946bp \\
\hline Gb_ba:Bormetg & L32146 & $\begin{array}{l}\text { metG (methionyl tRNA } \\
\text { synthetase) }\end{array}$ & 212 & $12 / 94$ & $346 b p$ \\
\hline Gb_ba:Borplsctop & L32861 & $\begin{array}{l}\text { parE (topoisomerase IV, B } \\
\text { subunit), plsC (1-acyl-sn- } \\
\text { glycerol-3-phosphate } \\
\text { acetyltransferase) }\end{array}$ & 212 & $5 / 94$ & $677 \mathrm{bp}$ \\
\hline Gb_ba:Bbysc1 & X78708 & $\begin{array}{l}\text { pep APE1 (aminopepti-dase } 1 \\
\text { homologue) }\end{array}$ & ZS7 & $4 / 94$ & $1,776 \mathrm{bp}$ \\
\hline Gb_ba:Borpgktpi & L32595 & $\begin{array}{l}\text { pgk (phosphoglycerate kinase), } \\
\text { tpi (triose-phosphate isomerase) }\end{array}$ & 212 & $5 / 94$ & $370 \mathrm{bp}$ \\
\hline Gb_ba:Borpthh & L32144 & pth (peptidyl-tRNA hydrolase) & 212 & $4 / 94$ & $910 \mathrm{bp}$ \\
\hline Gb_ba:Bbu23457 & U23457 & $\begin{array}{l}\text { recA General recombi-nation \& } \\
\text { DNA repair }\end{array}$ & Sh-2-82 & $4 / 96$ & $2,025 \mathrm{bp}$ \\
\hline Gb_ba:Borrho & L07656 & rho (Rho protein) & Sh-2-82 & $9 / 93$ & $1,499 \mathrm{bp}$ \\
\hline Gb_ba:Borrpob & L48488 & $\begin{array}{l}\text { rpoB rpoC (RNA polymerase, } \\
\text { beta \& beta prime subunits) }\end{array}$ & B31 & $11 / 95$ & $3,682 \mathrm{bp}$ \\
\hline Gb_ba:Borrhoa & L46347 & rho (Rho protein) & 212 & $8 / 95$ & $571 b p$ \\
\hline Gb_ba:Bbu35673 & U35673 & rpsT (30S ribosomal protein S20) & Sh-2-82 & $10 / 95$ & $3,399 \mathrm{bp}$ \\
\hline Gb_ba:Bbrnasep & U17591 & rpoD (primary sigma factor) & B31 & $12 / 94$ & $4,165 \mathrm{bp}$ \\
\hline Gb_ba:Bortufz & L23125 & tuf (elongation factor EF-Tu) & B31 & $8 / 93$ & $1,230 \mathrm{bp}$ \\
\hline
\end{tabular}

Table 6. 
3.6 Borrelia burgdorferi chromosomal sequences (Antigens and proteins of unknown function)

\begin{tabular}{|c|c|c|c|c|c|}
\hline $\begin{array}{l}\text { Genbank } \\
\text { mnemomic }\end{array}$ & $\begin{array}{l}\text { Accession } \\
\text { number }\end{array}$ & Description & Strain & $\begin{array}{l}\text { Date of } \\
\text { entry }\end{array}$ & Size \\
\hline Gb_ba:Bororf & L32797 & p21 (21 kDa protein) & & $5 / 95$ & $1,152 b p$ \\
\hline Gb_ba:Borunk & L31615 & p21A (21 kD protein) & 297 & $8 / 94$ & $700 \mathrm{bp}$ \\
\hline Gb_ba:Bor22kdant & M90084 & p22 (22 kD antigen) & B31 & $10 / 93$ & 795bp \\
\hline Gb_ba:Borp22x & L22530 & $\begin{array}{l}\text { p22X (22 kD outer surface } \\
\text { lipoprotein) }\end{array}$ & N40 & $8 / 94$ & $585 b p$ \\
\hline Gb_ba:Borp23a & L31616 & p23 (23kD protein) & 297 & $8 / 94$ & $686 b p$ \\
\hline Gb_ba:Bbhypp & X63898 & $\begin{array}{l}\text { p38 (38 kD ATP-binding } \\
\text { protein) }\end{array}$ & GeHo & $2 / 92$ & $1,435 \mathrm{bp}$ \\
\hline Gb_ba:Bdna66kd & X87725 & p66 (66 kD protein) & B31 & $6 / 95$ & $2,180 \mathrm{bp}$ \\
\hline Gb_ba:Borlyme & L32596 & p66 (66 kD protein) & 212 & $6 / 92$ & $240 \mathrm{bp}$ \\
\hline Gb_ba:Bbp831001 & X81514 & p93/p100 (93 kD protein) & 297 & $7 / 95$ & $287 \mathrm{bp}$ \\
\hline Gb_ba:Bbbop93 & X69601 & p93 (93 kD protein) & $\mathrm{BO}$ & $12 / 93$ & $1,991 b p$ \\
\hline Gb_ba:Bbp97 & X77749 & p97 (97 kD protein) & GOE2 & $6 / 95$ & $2,082 b p$ \\
\hline Gb_ba:Bbp831002 & X81520 & p93/p100 (93 kD protein) & pacificus & $7 / 95$ & $269 \mathrm{bp}$ \\
\hline Gb_ba:Bbp83100 & X81357 & p83/p100 (100 kD protein) & PBre & $4 / 96$ & $287 \mathrm{bp}$ \\
\hline Gb_ba:Bbp831003 & X81528 & p93/p100 (93 kD protein) & PKa2 & $7 / 95$ & $287 \mathrm{bp}$ \\
\hline Gb_ba:Bbp831004 & X81531 & p93/p100 (93 kD protein) & $\mathrm{T} 255$ & $7 / 95$ & $287 \mathrm{bp}$ \\
\hline Gb_ba:Bbtrop93 & X69604 & p93 (93 kD protein) & TRO & $12 / 93$ & $2,081 b p$ \\
\hline Gb_ba:Borsurant & L36037 & surface antigen & Dk1 & $9 / 94$ & $185 b p$ \\
\hline Gb_ba:Bbla7 & X70826 & LA7 (21 kD lipoprotein) & ZS7 & $11 / 93$ & $821 b p$ \\
\hline Gb_ba: & X91965 & $\begin{array}{l}a b p \text { (probable ATP binding } \\
\text { protein) }\end{array}$ & 212 & $9 / 95$ & $285 b p$ \\
\hline Gb_ba:Boraaa & M60802 & immunogen gene & & $12 / 92$ & $2,258 b p$ \\
\hline Gb_ba:Bbu18292 & U18292 & "bbk2.10 gene" & 297 & 7/95 & $1,799 \mathrm{bp}$ \\
\hline Gb_ba:Bbu19105 & U19105 & "bbk2.10 gene" & N40 & $7 / 95$ & $832 b p$ \\
\hline Gb_ba:Borlyme & L32596 & PCR target & 212 & $8 / 94$ & $240 \mathrm{bp}$ \\
\hline
\end{tabular}




\begin{tabular}{|c|c|c|c|c|c|}
\hline $\begin{array}{l}\text { Genbank } \\
\text { mnemomic }\end{array}$ & $\begin{array}{l}\text { Accession } \\
\text { number }\end{array}$ & Description & Strain & $\begin{array}{l}\text { Date of } \\
\text { entry }\end{array}$ & Size \\
\hline Gb_ba:Borseqa & M58429 & PCR target & & $3 / 91$ & $379 \mathrm{bp}$ \\
\hline Gb_ba:Borseqc & M58431 & PCR target & & $3 / 91$ & 1725bp \\
\hline Gb_ba:Borseqd & M58432 & PCR target & & $3 / 91$ & $381 b p$ \\
\hline Gb_ba:Borseqe & M58433 & PCR target & & $3 / 91$ & $379 b p$ \\
\hline Gb_ba:Bbu35673 & U35673 & $\begin{array}{l}\text { orfH, orfR and } h b b U \text { (putative } \\
\text { proteins) }\end{array}$ & Sh-2-82 & $10 / 95$ & 3,399bp \\
\hline
\end{tabular}

Table 7.

\section{Plasmid-encoded genes}

- ospA genes

- ospB genes

- ospC genes

- ospD genes

\subsection{Borrelia burgdorferi Plasmid-encoded sequences (Except ospA, ospB, ospC \& ospD)}

\begin{tabular}{|c|c|c|c|c|c|c|}
\hline $\begin{array}{l}\text { Genbank } \\
\text { mnemomic }\end{array}$ & $\begin{array}{l}\text { Accession } \\
\text { number }\end{array}$ & Description & Plasmid & Strain & $\begin{array}{l}\text { Date of } \\
\text { entry }\end{array}$ & Size \\
\hline $\begin{array}{l}\text { Gb_ba: } \\
\text { Borgmpguaa }\end{array}$ & L25883 & guaA (GMP synthetase) & $26 \mathrm{~kb} \mathrm{cp}$ & $\begin{array}{l}\text { CA- } \\
11.2 \mathrm{~A}\end{array}$ & $11 / 94$ & $1,599 \mathrm{bp}$ \\
\hline Gb_ba:Bbu13372 & U13372 & guaB (IMP dehydrogenase) & $26 \mathrm{~kb} \mathrm{cp}$ & $\begin{array}{l}\text { CA- } \\
11.2 \mathrm{~A}\end{array}$ & $11 / 94$ & $1,212 b p$ \\
\hline Gb_ba:Borospea & L13924 & $\operatorname{osp} E$ (outer surface protein E) & $45 \mathrm{~kb}$ lp & N40 & $3 / 94$ & $644 b p$ \\
\hline Gb_ba:Borospfa & L13925 & $\operatorname{ospF}$ (outer surface protein F) & $45 \mathrm{~kb} \mathrm{lp}$ & N40 & $3 / 94$ & $785 b p$ \\
\hline Gb_ba:Bbu19754 & U19754 & ospF (outer surface protein F) & $45 \mathrm{~kb} \mathrm{lp}$ & 297 & $7 / 95$ & $690 b p$ \\
\hline Gb_ba:Bbospg & X82409 & $\begin{array}{l}o s p G \& \text { bapA (outer surface } \\
\text { protein G \& associated } \\
\text { protein A) }\end{array}$ & $48 \mathrm{~b} \mathrm{lp}$ & ZS7 & $11 / 95$ & $1524 b p$ \\
\hline Gb_ba:Bbu22451 & U22451 & p12 (12kDa lipoprotein) & $49 \mathrm{~kb} \mathrm{lp}$ & B31 & 3/95 & $285 b p$ \\
\hline $\begin{array}{l}\text { Gb_ba: } \\
\text { Borexpprtn }\end{array}$ & L16625 & $\begin{array}{l}\text { p20 (exported neuro-toxin- } \\
\text { like protein) }\end{array}$ & $9 \mathrm{~kb} c \mathrm{p}$ & B31 & $8 / 94$ & $720 \mathrm{bp}$ \\
\hline Gb_ba:S66708 & S66708 & PCR target sequence & $30 \mathrm{~kb} \mathrm{cp}$ & B31 & $11 / 95$ & 416bp \\
\hline
\end{tabular}




\begin{tabular}{|c|c|c|c|c|c|c|}
\hline $\begin{array}{l}\text { Genbank } \\
\text { mnemomic }\end{array}$ & $\begin{array}{l}\text { Accession } \\
\text { number }\end{array}$ & Description & Plasmid & Strain & $\begin{array}{l}\text { Date of } \\
\text { entry }\end{array}$ & Size \\
\hline Gb_ba:Bors1a & L34016 & S1 antigen & $49 \mathrm{~kb} \mathrm{lp}$ & N40 & $11 / 95$ & $1,421 b p$ \\
\hline Gb_ba:Bors2a & L34016 & S2 antigen & $49 \mathrm{~kb}$ lp & N40 & $11 / 95$ & $837 b p$ \\
\hline $\begin{array}{l}\text { Gb_ba: } \\
\text { Bbptl4916 }\end{array}$ & X53311 & telomeres pTL16 and pTL49 & $\begin{array}{l}16 \mathrm{~kb} \text { lp } \\
\& 49 \mathrm{~kb} \\
\mathrm{lp}\end{array}$ & & $2 / 93$ & 238bp \\
\hline Gb_ba:Bbptr16 & X53312 & telomere pTR16 & $16 \mathrm{~kb}$ lp & & $2 / 93$ & 191bp \\
\hline Gb_ba:S65114 & S65114 & $\begin{array}{l}\text { left terminal repeat, } \\
\text { telomeric fragment }\end{array}$ & lp & & $7 / 92$ & $38 b p$ \\
\hline Gb_ba: & X87127 & repeated DNA element & $30.5 \mathrm{~kb} \mathrm{cp}$ & & $4 / 96$ & $5,500 \mathrm{bp}$ \\
\hline
\end{tabular}

Table 8.

\subsection{Borrelia burgdorferi ospA sequences}

\begin{tabular}{|c|c|c|c|c|c|}
\hline $\begin{array}{l}\text { Genbank } \\
\text { mnemomic }\end{array}$ & $\begin{array}{l}\text { Accession } \\
\text { number }\end{array}$ & Description & Strain & $\begin{array}{l}\text { Date of } \\
\text { entry }\end{array}$ & Size \\
\hline Gb_ba:Bb297ospa & X85442 & osp A (outer surface protein A) & 297 & $8 / 95$ & $822 b p$ \\
\hline Gb_ba:Borospad & L23138 & $\begin{array}{l}\operatorname{osp} A \operatorname{osp} B \text { (outer surface } \\
\text { proteins A \& B) }\end{array}$ & $19535 N Y 2$ & $8 / 94$ & $1,653 b p$ \\
\hline Gb_ba:Borospah & L23141 & $\begin{array}{l}\operatorname{osp} A \text { osp B (outer surface } \\
\text { proteins A \& B) }\end{array}$ & 21343WI & $8 / 94$ & $1,653 b p$ \\
\hline Gb_ba:Borospac & L23137 & $\begin{array}{l}\operatorname{osp} A \text { osp B (outer surface } \\
\text { proteins A \& B) }\end{array}$ & 27985CT2 & $6 / 94$ & $1,653 b p$ \\
\hline Gb_ba:Borospaf & L23140 & $\begin{array}{l}\operatorname{osp} A \text { osp B (outer surface } \\
\text { proteins A \& B) }\end{array}$ & 41552MA & $8 / 94$ & $1,653 b p$ \\
\hline Gb_ba:Borospae & L23139 & $\begin{array}{l}\operatorname{osp} A \text { osp B (outer surface } \\
\text { proteins A \& B) }\end{array}$ & $42373 N Y 3$ & $8 / 94$ & $1,653 b p$ \\
\hline Gb_ba:Borospaa & L23136 & $\begin{array}{l}\operatorname{osp} A \text { osp B (outer surface } \\
\text { proteins A \& B) }\end{array}$ & B19CT1 & $6 / 94$ & $1,653 b p$ \\
\hline Gb_ba:Bbospab & X14407 & $\begin{array}{l}\operatorname{osp} A \text { osp B (outer surface } \\
\text { proteins A \& B) }\end{array}$ & B31 & $9 / 94$ & $1,915 b p$ \\
\hline Gb_ba:Boropsab & L19701 & $\begin{array}{l}\operatorname{osp} A \text { osp B (outer surface } \\
\text { proteins A \& B) }\end{array}$ & B31 & $6 / 93$ & $1,916 b$ \\
\hline
\end{tabular}




\begin{tabular}{|c|c|c|c|c|c|}
\hline $\begin{array}{l}\text { Genbank } \\
\text { mnemomic }\end{array}$ & $\begin{array}{l}\text { Accession } \\
\text { number }\end{array}$ & Description & Strain & $\begin{array}{l}\text { Date of } \\
\text { entry }\end{array}$ & Size \\
\hline Gb_ba:Borospai & L23142 & $\begin{array}{l}\operatorname{osp} A \operatorname{osp} B \text { (outer surface } \\
\text { proteins A \& B) }\end{array}$ & CA3 & $8 / 94$ & $1,653 \mathrm{bp}$ \\
\hline Gb_ba:Borospaj & L23143 & $\begin{array}{l}\operatorname{osp} A \operatorname{osp} B \text { (outer surface } \\
\text { proteins A \& B) }\end{array}$ & CA7 & $8 / 94$ & $1,653 b p$ \\
\hline Gb_ba:Borospak & L23144 & $\begin{array}{l}\operatorname{osp} A \operatorname{osp} B \text { (outer surface } \\
\text { proteins A \& B) }\end{array}$ & CA8 & $8 / 94$ & $1,653 b p$ \\
\hline Gb_ba:Bbdk6ospa & X83622 & ospA (outer surface protein A) & DK6 & $1 / 95$ & $822 b p$ \\
\hline Gb_ba:Bbpospa & X63412 & ospA (outer surface protein A) & DK29 & $1 / 94$ & $825 b p$ \\
\hline Gb_ba:Bormajospr & L19702 & ospA (outer surface protein A) & G2 & $6 / 93$ & 2,123bp \\
\hline Gb_ba:Bbaspa & X60300 & ospA (outer surface protein A) & Goe2 & $12 / 92$ & $1,361 b p$ \\
\hline Gb_ba:Borospaa & L23136 & $\begin{array}{l}\operatorname{osp} A \text { osp B (outer surface } \\
\text { proteins A \& B) }\end{array}$ & HB19CT1 & $6 / 94$ & $1,653 b p$ \\
\hline Gb_ba:Bbospa3 & X65600 & ospA (outer surface protein A) & $\mathrm{HE}$ & $1 / 94$ & $822 b p$ \\
\hline Gb_ba:Bbu33179 & U33179 & ospA (outer surface protein A) & HT29 & $9 / 95$ & $270 b p$ \\
\hline Gb_ba:Bbopsaa & X70365 & ospA (outer surface protein A) & IP3 & $5 / 94$ & $822 b p$ \\
\hline Gb_ba:Bbka0spa & X69606 & $\operatorname{osp} A$ (outer surface protein A) & KA & $5 / 94$ & $822 b p$ \\
\hline Gb_ba:Bbospcmul & X84779 & ospA (outer surface protein A) & MUL & $5 / 95$ & $534 b p$ \\
\hline Gb_ba:Borfra & L38657 & ospA (outer surface protein A) & N3 & $1 / 95$ & $822 \mathrm{bp}$ \\
\hline Gb_ba:Borospa & M57248 & ospA (outer surface protein A) & N40 & $11 / 91$ & $819 \mathrm{bp}$ \\
\hline Gb_ba:Bbdnaospa & X85739 & ospA (outer surface protein A) & PBre & $9 / 95$ & $822 \mathrm{bp}$ \\
\hline Gb_ba:Bbpheiosp & X80251 & ospA (outer surface protein A) & PHei & 9/95 & $822 \mathrm{bp}$ \\
\hline Gb_ba:Bbpkaospa & X80182 & osp A (outer surface protein A) & PKa & 9/95 & $822 b p$ \\
\hline Gb_ba:Bbpwud1 & X80184 & ospA (outer surface protein A) & PWud1 & 9/95 & $822 b p$ \\
\hline Gb_ba:Bbpwudi & X68540 & ospA (outer surface protein A) & PWudI & $3 / 93$ & $333 b p$ \\
\hline Gb_ba:Bbpwudl6 & X80185 & ospA (outer surface protein A) & PWud1/6 & 9/95 & $822 b p$ \\
\hline Gb_ba:Bbpwudll & X80253 & ospA (outer surface protein A) & PWud11 & 9/95 & $825 b p$ \\
\hline
\end{tabular}




\begin{tabular}{|l|l|l|l|l|l|l|}
\hline $\begin{array}{l}\text { Genbank } \\
\text { mnemomic }\end{array}$ & $\begin{array}{l}\text { Accession } \\
\text { number }\end{array}$ & Description & Strain & $\begin{array}{l}\text { Date of } \\
\text { entry }\end{array}$ & Size \\
\hline Gb_ba:Bbpwudii & X68539 & ospA (outer surface protein A) & PWudII & $3 / 93$ & $333 \mathrm{bp}$ \\
\hline Gb_ba:Bor90ospa & L42873 & ospA (outer surface protein A) & SIMON & $6 / 95$ & $582 \mathrm{bp}$ \\
\hline Gb_ba:Bbt25ospa & X85443 & ospA (outer surface protein A) & T255 & $9 / 95$ & $822 \mathrm{bp}$ \\
\hline Gb_ba:Borospaab & D29660 & ospA (outer surface protein A) & tick isolate & $4 / 95$ & $911 \mathrm{bp}$ \\
\hline Gb_ba:Bbospa1 & X65598 & ospA (outer surface protein A) & TRO & $1 / 94$ & $822 \mathrm{bp}$ \\
\hline Gb_ba:Bbospa & X16467 & ospA (outer surface protein A) & ZS7 & $9 / 93$ & $942 \mathrm{bp}$ \\
\hline Gb_ba:A22442 & A22442 & ospA (outer surface protein A) & ZS7 & $12 / 94$ & $822 \mathrm{bp}$ \\
\hline Gb_ba:Bbosproa & X66065 & ospA (outer surface protein A) & ZQ1 & 7/93 & $825 \mathrm{bp}$ \\
\hline Gb_ba:A24006 & A24006 & ospA (outer surface protein A) & ZQ1 & 2/95 & $825 \mathrm{bp}$ \\
\hline Gb_ba:A04009 & A04009 & $\begin{array}{l}\text { ospA ospB (outer surface } \\
\text { proteins A \& B) }\end{array}$ & & $4 / 93$ & $1,915 \mathrm{bp}$ \\
\hline
\end{tabular}

Table 9.

\subsection{Borrelia burgdorferi ospB sequences}

\begin{tabular}{|l|l|l|l|l|l|}
\hline $\begin{array}{l}\text { Genbank } \\
\text { mnemomic }\end{array}$ & $\begin{array}{l}\text { Accession } \\
\text { number }\end{array}$ & Description & Strain & $\begin{array}{l}\text { Date of } \\
\text { entry }\end{array}$ & Size \\
\hline Gb_ba:Borospad & L23138 & $\begin{array}{l}\text { ospA ospB (outer surface } \\
\text { proteins A \& B) }\end{array}$ & 19535NY2 & $8 / 94$ & $1,653 \mathrm{bp}$ \\
\hline Gb_ba:Borospah & L23141 & $\begin{array}{l}\text { ospA ospB (outer surface } \\
\text { proteins A \& B) }\end{array}$ & $21343 \mathrm{WI}$ & $8 / 94$ & $1,653 \mathrm{bp}$ \\
\hline Gb_ba:Borospac & L23137 & $\begin{array}{l}\text { ospA ospB (outer surface } \\
\text { proteins A \& B) }\end{array}$ & 27985CT2 & $6 / 94$ & $1,653 \mathrm{bp}$ \\
\hline Gb_ba:Borospaf & L23140 & $\begin{array}{l}\text { ospA ospB (outer surface } \\
\text { proteins A \& B) }\end{array}$ & $41552 \mathrm{MA}$ & $8 / 94$ & $1,653 \mathrm{bp}$ \\
\hline Gb_ba:Borospae & L23139 & $\begin{array}{l}\text { ospA ospB (outer surface } \\
\text { proteins A \& B) }\end{array}$ & $42373 \mathrm{NY3}$ & $8 / 94$ & $1,653 \mathrm{bp}$ \\
\hline Gb_ba:Boropsab & L19701 & $\begin{array}{l}\text { ospA ospB (outer surface } \\
\text { proteins A \& B) }\end{array}$ & B31 & $6 / 93$ & $1,916 \mathrm{~b}$ \\
\hline Gb_ba:Bbospab & X14407 & $\begin{array}{l}\text { ospA ospB (outer surface } \\
\text { proteins A \& B) }\end{array}$ & B31 & $9 / 94$ & $1,915 \mathrm{bp}$ \\
\hline
\end{tabular}




\begin{tabular}{|c|c|c|c|c|c|}
\hline $\begin{array}{l}\text { Genbank } \\
\text { mnemomic }\end{array}$ & $\begin{array}{l}\text { Accession } \\
\text { number }\end{array}$ & Description & Strain & $\begin{array}{l}\text { Date of } \\
\text { entry }\end{array}$ & Size \\
\hline Gb_ba:Bbospbb31 & X74808 & ospB (outer surface protein B) & B31 & $7 / 94$ & $934 b p$ \\
\hline Gb_ba:Bbospbev & X74810 & $\operatorname{csp} B$ (outer surface protein B) & B31/EVB & $7 / 94$ & $934 b p$ \\
\hline Gb_ba:Bbospbbp & X74809 & $\operatorname{osp} B$ (outer surface protein B) & BEP4 & $7 / 94$ & $934 \mathrm{bp}$ \\
\hline Gb_ba:Borospai & L23142 & $\begin{array}{l}\operatorname{osp} A \operatorname{osp} B \text { (outer surface } \\
\text { proteins A \& B) }\end{array}$ & CA3 & $8 / 94$ & $1,653 b p$ \\
\hline Gb_ba:Borospaj & L23143 & $\begin{array}{l}\text { osp } A \text { osp B (outer surface } \\
\text { proteins A \& B) }\end{array}$ & CA7 & $8 / 94$ & $1,653 b p$ \\
\hline Gb_ba:Borospak & L23144 & $\begin{array}{l}\operatorname{osp} A \operatorname{osp} B \text { (outer surface } \\
\text { proteins A \& B) }\end{array}$ & CA8 & $8 / 94$ & $1,653 \mathrm{bp}$ \\
\hline Gb_ba:Borospbvr & L31399 & $\operatorname{osp} B$ (outer surface protein B) & HB19 & $3 / 95$ & $891 b p$ \\
\hline Gb_ba:Borospaa & L23136 & $\begin{array}{l}\operatorname{osp} A \operatorname{osp} B \text { (outer surface } \\
\text { proteins A \& B) }\end{array}$ & HB19CT1 & $6 / 94$ & $1,653 \mathrm{bp}$ \\
\hline Gb_ba:A04009 & A04009 & $\begin{array}{l}\operatorname{osp} A \text { osp } B \text { (outer surface } \\
\text { proteins A \& B) }\end{array}$ & & $4 / 93$ & $1,915 \mathrm{bp}$ \\
\hline
\end{tabular}

Table 10.

\subsection{Borrelia burgdorferi ospC sequences}

\begin{tabular}{|l|l|l|l|l|l|}
\hline $\begin{array}{l}\text { Genbank } \\
\text { mnemomic }\end{array}$ & $\begin{array}{l}\text { Accession } \\
\text { number }\end{array}$ & Description & Strain & $\begin{array}{l}\text { Date of } \\
\text { entry }\end{array}$ & Size \\
\hline Gb_ba:Bbospc272 & X84785 & ospC (outer surface protein C) & 272 & $5 / 95$ & $534 \mathrm{bp}$ \\
\hline Gb_ba:Bbu08284 & U08284 & ospC (outer surface protein C) & 297 & $9 / 94$ & $579 \mathrm{bp}$ \\
\hline Gb_ba:Bor26ospc & L42893 & ospC (outer surface protein C) & 297 & $6 / 95$ & $576 \mathrm{bp}$ \\
\hline Gb_ba:Bbu01892 & U01892 & $\operatorname{ospC}$ (outer surface protein C) & 2591 & $1 / 94$ & $824 \mathrm{bp}$ \\
\hline Gb_ba:Bor32ospc & L42899 & $\operatorname{ospC}$ (outer surface protein C) & 21347 & $6 / 95$ & $576 \mathrm{bp}$ \\
\hline Gb_ba:Bor30ospc & L42897 & $\operatorname{ospC}$ (outer surface protein C) & 26815 & $6 / 95$ & $579 \mathrm{bp}$ \\
\hline Gb_ba:Bor29ospc & L42896 & $\operatorname{ospC}$ (outer surface protein C) & 27579 & $6 / 95$ & $573 \mathrm{bp}$ \\
\hline Gb_ba:Bor28ospc & L42895 & $\operatorname{ospC}$ (outer surface protein C) & 28354 & $6 / 95$ & $579 \mathrm{bp}$ \\
\hline Gb_ba:Bor27ospc & L42894 & $\operatorname{ospC}$ (outer surface protein C) & 28691 & $6 / 95$ & $573 \mathrm{bp}$ \\
\hline
\end{tabular}




\begin{tabular}{|c|c|c|c|c|c|}
\hline $\begin{array}{l}\text { Genbank } \\
\text { mnemomic }\end{array}$ & $\begin{array}{l}\text { Accession } \\
\text { number }\end{array}$ & Description & Strain & $\begin{array}{l}\text { Date of } \\
\text { entry }\end{array}$ & Size \\
\hline Gb_ba:Bbb31ospc & X69596 & $\operatorname{osp} C$ (outer surface protein C) & B31 & $5 / 93$ & $633 b p$ \\
\hline Gb_ba:Bbu01894 & U01894 & $\operatorname{osp} C$ (outer surface protein C) & B31 & $1 / 94$ & $980 \mathrm{bp}$ \\
\hline Gb_ba:Borospca & D49497 & $\operatorname{osp} C$ (outer surface protein C) & B31 & $5 / 95$ & $633 b p$ \\
\hline Gb_ba:Bbospcbur & X84765 & $\operatorname{ospC}$ (outer surface protein C) & BUR & $5 / 95$ & $534 b p$ \\
\hline Gb_ba:Borospc & L25413 & $\operatorname{ospC}$ (outer surface protein C) & CA-11.2A & $7 / 94$ & $1,150 \mathrm{bp}$ \\
\hline Gb_ba:Bbospce & X73626 & $\operatorname{osp} C$ (outer surface protein C) & DK6 & $2 / 94$ & $609 b p$ \\
\hline Gb_ba:Bbospcd & X73625 & $\operatorname{ospC}$ (outer surface protein C) & DK7 & $2 / 94$ & $618 b p$ \\
\hline Gb_ba:Bbospcc & X73624 & $\operatorname{ospC}$ (outer surface protein C) & DK26 & $2 / 94$ & $624 b p$ \\
\hline Gb_ba:Bbospcb & X73623 & $\operatorname{osp} C$ (outer surface protein $C$ ) & DK27 & $2 / 94$ & $624 b p$ \\
\hline Gb_ba:Bbospcduk & X84778 & $\operatorname{ospC}$ (outer surface protein $\mathrm{C}$ ) & DUNKIRK & $5 / 95$ & $528 b p$ \\
\hline Gb_ba:Bbu04281 & U04281 & $\operatorname{osp} C$ (outer surface protein $C$ ) & HB19 & $1 / 95$ & $692 b p$ \\
\hline Gb_ba:Bor20ospc & L42887 & $\operatorname{ospC}$ (outer surface protein C) & Ip2 & $6 / 95$ & $576 b p$ \\
\hline Gb_ba:Bbospckip & X84782 & $\operatorname{osp} C$ (outer surface protein $C$ ) & KIPP & $5 / 95$ & $534 \mathrm{bp}$ \\
\hline Gb_ba:Bbu04240 & U04240 & $\operatorname{ospC}$ (outer surface protein $\mathrm{C}$ ) & N40 & $8 / 94$ & $689 b p$ \\
\hline Gb_ba:Bbdnaospc & X83555 & $\operatorname{ospC}$ (outer surface protein C) & pacificus & $6 / 95$ & $630 \mathrm{bp}$ \\
\hline Gb_ba:Bbospc1 & X81522 & $\operatorname{osp} C$ (outer surface protein $C$ ) & PBre & $6 / 95$ & 636bp \\
\hline Gb_ba:Bbpkaospc & X69589 & $\operatorname{ospC}$ (outer surface protein C) & PKa & $2 / 94$ & $633 b p$ \\
\hline Gb_ba:Bbt25ospc & X69592 & $\operatorname{ospC}$ (outer surface protein $\mathrm{C}$ ) & T25 & $2 / 94$ & 636bp \\
\hline Gb_ba:Bbospc2 & X81524 & $\operatorname{ospC}$ (outer surface protein C) & T255 & $5 / 95$ & $633 b p$ \\
\hline Gb_ba:Bbospctxw & X84783 & $\operatorname{osp} C$ (outer surface protein $C$ ) & TXGW & $5 / 95$ & $531 b p$ \\
\hline Gb_ba:Bbwudospc & X69590 & $\operatorname{ospC}$ (outer surface protein $\mathrm{C}$ ) & WudI & $2 / 94$ & $639 \mathrm{bp}$ \\
\hline Gb_ba:Bor40ospc & L42868 & $\operatorname{osp} C$ (outer surface protein C) & ZS7 & $6 / 95$ & $579 b p$ \\
\hline
\end{tabular}

Table 11. 


\subsection{Borrelia burgdorferi ospD sequences}

\begin{tabular}{|l|l|l|l|l|l|}
\hline $\begin{array}{l}\text { Genbank } \\
\text { mnemomic }\end{array}$ & $\begin{array}{l}\text { Accession } \\
\text { number }\end{array}$ & Description & Strain & $\begin{array}{l}\text { Date of } \\
\text { entry }\end{array}$ & Size \\
\hline Gb_ba:Bbu05304 & U05304 & ospD (outer surface protein D) & 3028 & $11 / 94$ & $1,012 \mathrm{bp}$ \\
\hline Gb_ba:Bbu05305 & U05305 & ospD (outer surface protein D) & 27985 & $11 / 94$ & $1,012 \mathrm{bp}$ \\
\hline Gb_ba:Borospd & M97452 & ospD (outer surface protein D) & B31 & $2 / 93$ & $1,079 \mathrm{bp}$ \\
\hline Gb_ba:Bbu05324 & U05324 & ospD (outer surface protein D) & CA12 & $11 / 94$ & 9 $991 \mathrm{bp}$ \\
\hline Gb_ba:Borospdhb & L34055 & ospD (outer surface protein D) & HB19 & $6 / 94$ & $1,045 \mathrm{bp}$ \\
\hline Gb_ba:Bbu05327 & U05327 & ospD (outer surface protein D) & lp7 & $11 / 94$ & $1,064 \mathrm{bp}$ \\
\hline
\end{tabular}

Table 12.

\subsection{Borrelia burgdorferi fusion sequences}

\begin{tabular}{|l|l|l|l|l|l|}
\hline Genbank mnemomic & $\begin{array}{l}\text { Accession } \\
\text { number }\end{array}$ & Description & Strain & $\begin{array}{l}\text { Date of } \\
\text { entry }\end{array}$ & Size \\
\hline Gb_ba:A24010 & A24010 & ospA fusion & NS1 & $2 / 95$ & $1,020 \mathrm{bp}$ \\
\hline Gb_ba:A24012 & A24012 & ospA fusion & NS1 & $2 / 95$ & $1,014 \mathrm{bp}$ \\
\hline Gb_ba:A24014 & A24014 & ospA fusion & NS1 & $2 / 95$ & $1,017 \mathrm{bp}$ \\
\hline Gb_ba:A24016 & A24016 & ospA fusion & NS1 & $2 / 95$ & $1,017 \mathrm{bp}$ \\
\hline Gb_ba:Borbb1 & L31427 & phoA fusion & 297 & $4 / 95$ & $279 \mathrm{bp}$ \\
\hline Gb_ba:Borbb10 & L31421 & phoA fusion & 297 & $4 / 95$ & $319 \mathrm{bp}$ \\
\hline Gb_ba:Borbb11 & L31424 & phoA fusion & 297 & $4 / 95$ & $248 \mathrm{bp}$ \\
\hline Gb_ba:Borbb13 & L31422 & phoA fusion & 297 & $4 / 95$ & $354 \mathrm{bp}$ \\
\hline Gb_ba:Borbb14 & L31423 & phoA fusion & 297 & $4 / 95$ & $361 \mathrm{bp}$ \\
\hline Gb_ba:Borbb16 & L31425 & phoA fusion & 297 & $4 / 95$ & $135 \mathrm{bp}$ \\
\hline Gb_ba:Borbb17 & L31426 & phoA fusion & 297 & $4 / 95$ & 615bp \\
\hline Gb_ba:Borbb4 & L31417 & phoA fusion & 297 & $4 / 95$ & $294 \mathrm{bp}$ \\
\hline Gb_ba:Borbb4a & L31419 & L phoA fusion & 297. & $4 / 95$ & $221 \mathrm{bp}$ \\
\hline Gb_ba:Borbb5 & L31418 & phoA fusion & 297 & $4 / 95$ & $341 \mathrm{bp}$ \\
\hline
\end{tabular}

Table 13. 


\subsection{Borrelia burgdorferi promoter sequences}

\begin{tabular}{|l|l|l|l|l|l|}
\hline Genbank mnemomic & $\begin{array}{l}\text { Accession } \\
\text { number }\end{array}$ & Description & Strain & $\begin{array}{l}\text { Date of } \\
\text { entry }\end{array}$ & Size \\
\hline Gb_ba:Borproma & M28680 & promoter & B31 & $6 / 90$ & 194bp \\
\hline Gb_ba:Borpromb & M28681 & promoter & B31 & $6 / 90$ & 203bp \\
\hline Gb_ba:Borpromc & M28682 & promoter & B31 & $6 / 90$ & 78bp \\
\hline
\end{tabular}

Table 14.

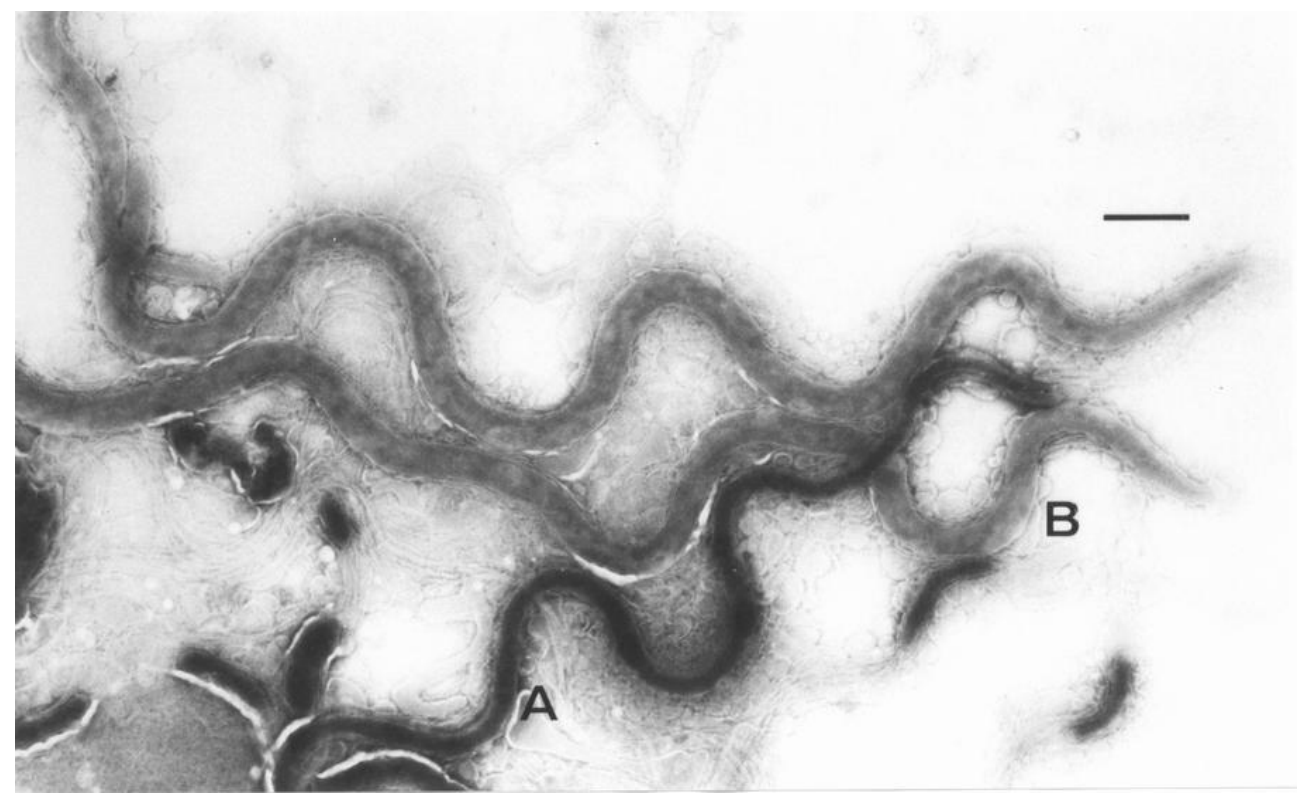

Fig. 5. Electron microscopy of unfixed, negative stained DK1 strain (skin isolate). This strain consist of two morphologically distinct borrelia A. small and B. larger borrelia. Bar $1 \mathrm{~mm}$. Magnification 10,260 x. 


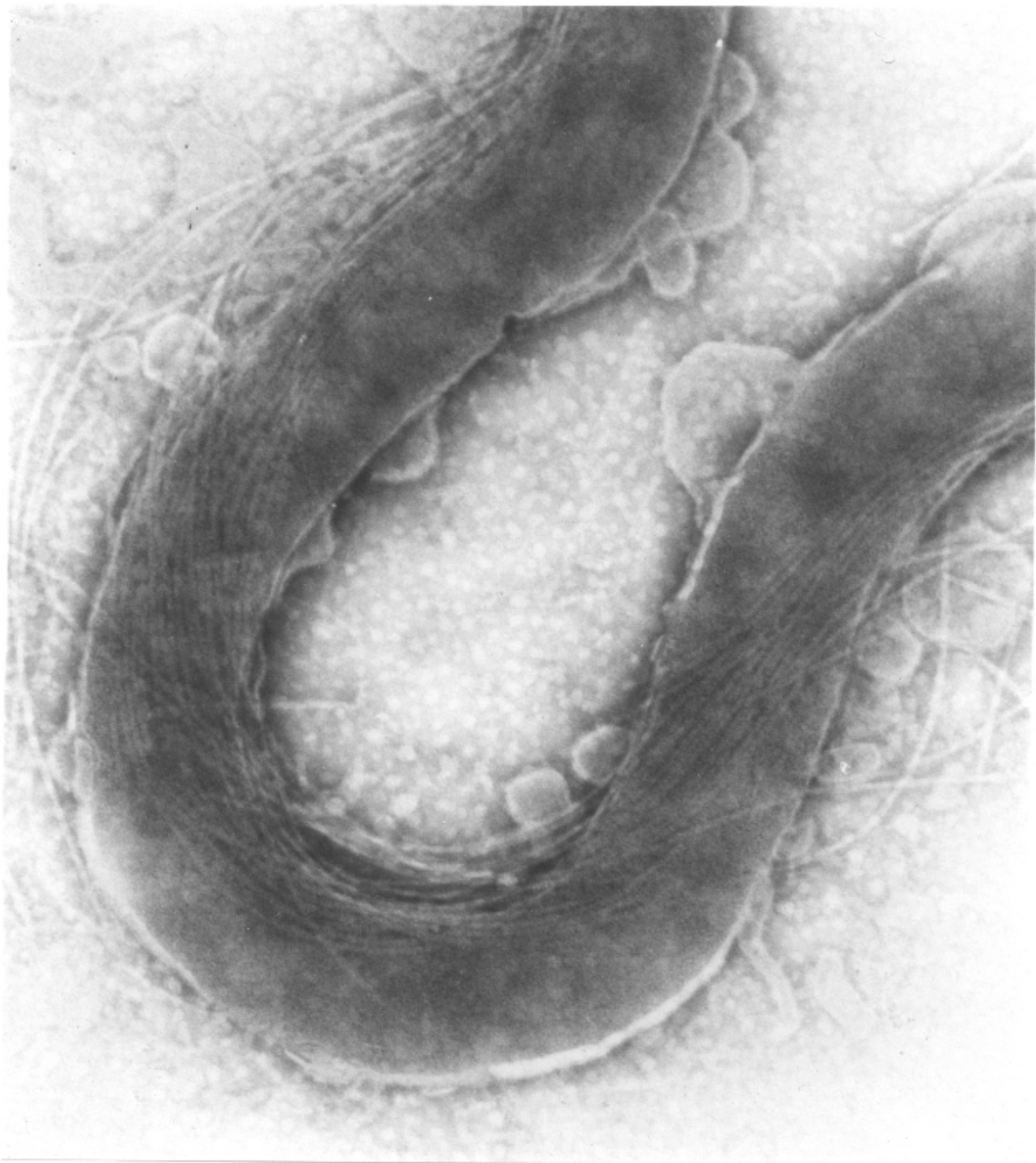

Fig. 6. Electron microscopy of unfixed, negative stained DK1 strain (skin isolate). 


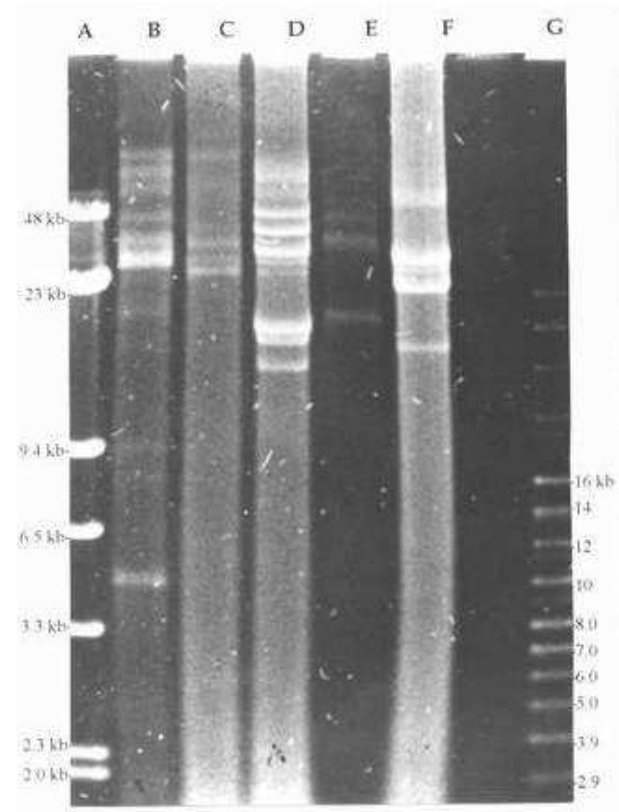

Fig. 7. Plasmids isolated from different strains of Borrelia burgdorferi : The Dk1 strain (B), Dk5 strain (C), DK6 strain (D), DK 2 strain (E), DK7 strain (F) and a super coiled circular molecular weight marker (G). Linear molecular markers (A) (HindIII fragments of Lambda DNA). Samples were separated in $0.3 \%$ gel at $14^{\circ} \mathrm{C}$ for $20 \mathrm{hr}$ then stained with ethidium bromide.

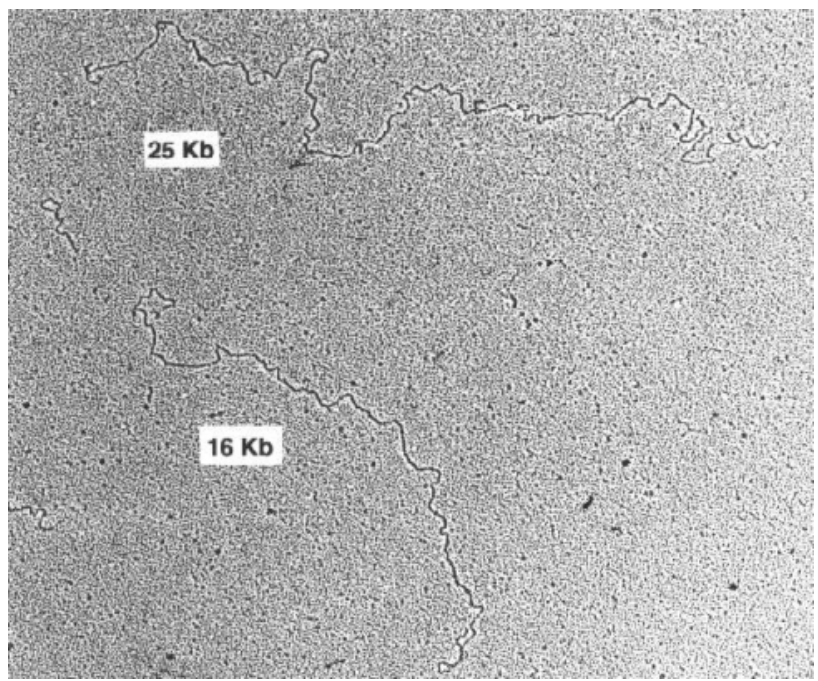

Fig. 8. Elrectron micrograph of $25 \mathrm{~kb}$ plasmid extracted from DK1 strain . One supercoiled plasmid. magnification $52000 \mathrm{x}$. 


\section{References}

Burgdorfer W, Barbour AG, Hayes SF, Benach JL, Grunwaldt E, Davis JP (June 1982). "Lyme disease-a tick-borne spirochetosis?". Science 216 (4552): 1317-9.

Barbour, A.G. (1984) Isolation and cultivation of Lyme disease spirochetes. Yale J Biol Med 57: 521-525.

Barbour, A. G. \& Garon, C. F., 1987. The Gene encoding major surface protein of Borrelia burgdorferi are located on a plasmid. Ann. NY. Acad. Sci., 539: 144-153.

Barbour, A. G. , 1988. Plasmid analysis of Borrelia burgdorferi, the Lyme disease agent. : J. Clin.Microbiol., 26: 475-478.

Barbour A.G. \& Garon. C. F., 1987.Linear plasmids of the bacterium Borrelia burgdorferi have covalently closed ends. Science., 237: 409-411 .

Shigekawa, K., and Dower, W.J. (1988) Electroporation of eukaryotes and prokaryotes: a general approach to the introduction of macromolecules into cells. BioTechniques 6: 742-751.

Barbour, A. G., 1989.Classification of Borrelia burgdorferi on the basis of plasmid profiles. Zbl.Bakt.Supl.,18: 1-7.

Barbour. A. G., 1989.The Molecular biology of Borrelia. Rev .Infec.Disease. 11 suppl $6 \mathrm{~s}$ : 1470-1474.

Bergstrom. S. Bundoc. V. G \& Barbour. A., 1989. Molecular analysis of linear plasmid encoded major surface protein, OspA and OspB, of the lyme disease spirochaete Borrelia burgdorferi. Mol.microbiol.,3: 479-486.

Crespi, M., Messense, E. A Caplan, M. Von Montagu \& Desomer, 1992. Fasciation Induction by the phytopatogen Rhodococoous fascians depends upon a linear plasmid Encoding a cytokinin synthase gene. EMBO. J., 11: 795-804.

Davidson .B. E, Mac Dugall J \& Girons. I. S., 1992. Physical map of the linear chromosome of the bacterium Borrelia burgdorferi, a causative agent of lyme disease, and localization of rRNA Genes. J.Bacteriol., 174: 3766-3774.

Ferdows .M. S, Barbour .A. G., 1989.Megabase-sized linear DNA in the bacterium Borrelia burgdorferi, the lyme disease agent. Proc.Natl. Acad.Sci.USA., 86: 5969-5973.

Hansen, K., hovmark, A., Lebech,A .m., Lebech,k., Olsson,I., Halkier,l ;et al. 1992. Roxithromycin in Lyme borreliosis: discrepant Results of in vitro and in vivo animal susceptibility study and clinical trial in patients with erythema migrans. Acta.Derm.Venerol., 72: 297-300.

Hinnebusch. J \& Barbour. A. G., 1991.Linear plasmids of Borrelia burgdorferi have a telomeric structure and sequence similar to those of eukaryotic virus. J. Bacteriol., 173: 7233-7239.

Schwan.T. G, Burgdorfer. W. \& Garon. C. F ., 1988. Change in Infectivity and Plasmid Profile of Lyme Disease Spirochete, Borrelia Borgdorferi, as a Result of In vitro cultivation. Inf. Immun ., 56: 1831-1836.

Servent, A. A., Charachon, S, Y., Bilak,E, J., Karayan, L. \& Ramuz .M., 1993. Presence of one linear and one circular chromosome in the Agrobacterium tumefaciens C58 genome. J. bacteriol., 175: 7869-7874.

Sherwood, C \& Wai .M.H.,1993. Linear chromosomal and genetic map of Borrelia burgdorferi, the lyme disease Agent. Molecular miccrobiol., 8 (5): 967-980. 
A G Barbour, C J Carter, V Bundoc, and J Hinnebusch. The nucleotide sequence of a linear plasmid of Borrelia burgdorferi reveals similarities to those of circular plasmids of other prokaryotes.J Bacteriol. 1996 November; 178(22): 6635-6639.

Fraser CM, Casjens S, Huang WM, et al. (December 1997). "Genomic sequence of a Lyme disease spirochaete, Borrelia burgdorferi". Nature 390 (6660): 580-6.

Bundoc, V.G., and Barbour, A.G. (1989) Clonal polymorphisms of outer membrane protein OspB of Borrelia burgdorferi. Infect Immun 57: 2733-2741.

Hinnebusch, J., and Tilly, K. (1993) Linear plasmids and chromosomes in bacteria. Mol Microbiol 10: 917-922.

Rosa, P., Samuels, D.S., Hogan, D., Stevenson, B., Casjens, S., and Tilly, K. (1996) Directed insertion of a selectable marker into acircular plasmid of Borrelia burgdorferi. J Bacteriol 178: 5946-5953.

Saint Girons, I., Old, I.G., and Davidson, B.E. (1994) Molecular biology of the Borrelia, bacteria with linear replicons. Microbiology 140: 1803-1816.

Samuels, D.S., and Garon, C.F. (1993) Coumermycin A1 inhibits growth and induces relaxation of supercoiled plasmids in Borrelia burgdorferi, the Lyme disease agent. Antimicrob Agents Chemother 37: 46-50.

Tilly, K., Casjens, S., Stevenson, B., Bono, J., Samuels, D.S., Hogan, D. and Rosa, P. (1997) The Borrelia burgdorferi circular plasmid cp26: conservation of plasmid structure and targeted inactivation of the $\operatorname{ss} \mathrm{C}$ gene. Mol. Microbiol. 25:361-373.

Ali Karami , Peter Hindeersson, Niels Hoiby, Saeid Morovvati and Akbar Khalilpour. Linear and Circular Plasmids in Skin and Cerebrospinal Fluid Isolates of Borrelia burgdorferi Agent of Lyme Disease. Pakistan Journal of Biological Sciences 2006 (9): $15,2787-2793$

Ali KARAMI, Seyed Mohammad Javad HOSSEYNI, Yaser KIARUDI .Molecular Characterization of Borrelia burgdorferi Linear Plasmids by DNA Hybridization, PCR, Two-Dimensional Gel Electrophoresis, and Electron Microscopy. Turk J Biol 31 (2007) 73-80.

A Karami, P Hindersson, N Høiby, S Morovvati. OspA Sequence Comparison and Protection Against Borrelia burgdorferi Infection in Gerbils by Recombinant OspA Protein. Iranian Journal of Public Health 2006;35(2):16-24.

Sorouri R, Ranjbar R, Jonaidi Jafari N, Karami A. Rapid detection of Borrelia burgdorferi strains by nested polymerase chain reaction. Pak J Biol Sci. 2009 Mar 1;12(5):463-6.

Galdwin, Mark; Trattler, Bill (2009). Spirochetes: Clinical Microbiology Made Ridiculously Simple. MedMaster, Inc. ISBN 978-0-940780-81-1.

Samuels DS; Radolf, JD. (2010). Borrelia: Molecular Biology, Host Interaction and Pathogenesis. Caister Academic Press. ISBN 978-1-904455-58-5. 


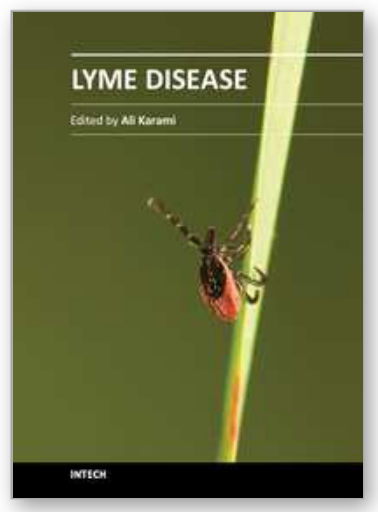

\author{
Lyme Disease \\ Edited by Dr. Ali Karami
}

ISBN 978-953-51-0057-7

Hard cover, 160 pages

Publisher InTech

Published online 17, February, 2012

Published in print edition February, 2012

Lyme disease, or Lyme borreliosis, is an emerging infectious disease caused by bacteria belonging to the genus borrelia. Borrelia burgdorferi, in the strict sense. This book deals mostly with the molecular biology of the Lyme disease agent orrelia burgdorferi. It has been written by experts in the relevant field and is tailored to the need of researchers, advanced students of biology, molecular biology, molecular genetics of microorganism. It will also be of use to infectious disease experts and people in other disciplines needing to know more about Lyme borreliosis. The book contains chapters on the molecular biology of the Lyme disease agent, zoonotic peculiarities of $\mathrm{Bb}$, advancement in $\mathrm{Bb}$ antibody testing, the serology diagnostic schemes in $\mathrm{Bb}$, discovering Lyme disease in ticks and dogs, adaptation to glucosamine starvation in $\mathrm{Bb}$, and porins in the genus borrelia.

\title{
How to reference
}

In order to correctly reference this scholarly work, feel free to copy and paste the following:

Ali Karami (2012). Molecular Biology of Borrelia burgdorferi, Lyme Disease, Dr. Ali Karami (Ed.), ISBN: 978953-51-0057-7, InTech, Available from: http://www.intechopen.com/books/lyme-disease/-molecular-biology-oflyme-disease-agent-

\section{INTECH}

open science | open minds

\section{InTech Europe}

University Campus STeP Ri

Slavka Krautzeka 83/A

51000 Rijeka, Croatia

Phone: +385 (51) 770447

Fax: +385 (51) 686166

www.intechopen.com

\section{InTech China}

Unit 405, Office Block, Hotel Equatorial Shanghai

No.65, Yan An Road (West), Shanghai, 200040, China

中国上海市延安西路65号上海国际贵都大饭店办公楼 405 单元

Phone: +86-21-62489820

Fax: +86-21-62489821 
(C) 2012 The Author(s). Licensee IntechOpen. This is an open access article distributed under the terms of the Creative Commons Attribution 3.0 License, which permits unrestricted use, distribution, and reproduction in any medium, provided the original work is properly cited. 